\title{
Sodium Arsenite Induced Systemic Organ Damage and Changes in Various Blood Parameters in Mice
}

\author{
Rim Sabrina J ahan Sarker, Nazmul Ahsan and Anwarul Azim Akhand
}

Department of Genetic Engineering and Biotechnology, University of Dhaka, Dhaka-1000, Bangladesh.

\begin{abstract}
In this study, we examined the toxic effects of arsenic in vivo taking mice as a model animal. Swiss albino mice with similar weights were divided into two groups. The mice belonging to the first group were used as the control, while the other group was exposed to sodium arsenite (SA) through drinking water. Compared to control, the level of hemoglobin in SA-exposed mice was decreased while the number of neutrophils and monocytes were increased. In addition, SA also induced increase in liver and spleen weight within 8 weeks of exposure. In contrast, the weight of the kidney was found to decrease. These findings in mice model might be useful for better understanding of the toxic effects of arsenic in order to develop effective remediation process against arsenicmediated effects on human health.
\end{abstract}

Key words: Arsenic, hemoglobin, spleen enlargement.

\section{INTRODUCTION}

Arsenic is known to most people for its long history of being a deadly poison. This poison created a major health concern affecting millions of people around the world, including Bangladesh. People in Bangladesh are mainly exposed to arsenic through drinking water. ${ }^{1-3}$ Ingested inorganic arsenic is readily absorbed through the gastrointestinal tract and distributed in various tissues through blood circulation. ${ }^{4}$ This arsenic eventually causes growth retardation, blood cells distortion and elevation of various serum enzymes like lactate dehydrogenase (LDH), alkaline phosphatase (ALP), serum glutamic pyruvic transaminase (SGPT) etc. in human and rodents. ${ }^{5,6}$ Chronic arsenic exposure is accompanied by its accumulation in liver, kidney, heart, lung, gastrointestinal tract and spleen. ${ }^{1,7-9}$ Hepatic damage has been reported as the most common complication of chronic arsenic exposures. ${ }^{6,10,11}$ Although the toxic effects of arsenic are known for long time, the mechanism of its toxicity is still poorly understood.

Correspondence to: Anwarul Azim Akhand

Cell: 88-01911176126

Tel: 880-2-9661920/7817

E-mail: akhand66@yahoo.com

Dhaka Univ. J. Pharm. Sci. 11(2): 169-172, 2012 (December)
One of the known functions of arsenic is its high reactivity to sulfhydryl groups of proteins/enzymes. Binding of arsenic to proteins or cross-linking of proteins involving sulfhydryl group may activate potential intracellular signaling pathways that ultimately lead to arsenic-mediated adverse effects. ${ }^{12-14}$ To understand the arsenic-mediated health hazards in human, experiments with human subjects is almost impossible for various legal reasons. Suitable animal model experiments, however, can help in this regard. Thus in our study, we selected Swiss albino mice as a model organism for exposing arsenic for 8 weeks to find out the in vivo effects of arsenic. By comparison with control, the visible and clinical manifestations at tissue/organ or blood levels would help us to understand the effects of arsenic poisoning.

\section{MATERIALS AND METHODS}

Animal maintenance. Swiss albino male mice ( 6 weeks of age) of average body weight $(30.12 \pm 0.58$ g) were purchased from the Animal Resource Division of International Center for Diarrhoeal Disease and Research, Bangladesh (ICDDR, B). The mice were kept in plastic cages with wood-cobe bedding (5 mice/cage). After one week of 
acclimation, they were divided into two groups, control, and experimental mice. Control mice were maintained with available supply of distilled water and normal mice feed. The mice of experimental group (SA) were given normal feed and sodium arsenite $\left(\mathrm{NaAsO}_{2}\right)$ containing water $(0.2 \mathrm{~g} / \mathrm{l})$. These two groups of mice were maintained for 8 weeks. All experiments using mice were undertaken following the standard laboratory handling procedures and ethical issues.

Blood collection, differential counting of white blood cells (WBC) and estimation of hemoglobin (Hb) level. Surgical blade (size 11) was pinched sharply between ear and eye of mice. Blood came out as drops were collected in EDTA coated plastic tubes to prevent coagulation. Differential counting of WBC such as lymphocytes, eosinophils, neutrophils and monocytes were conducted by using a Cell Counter 1210 (an automatic blood cell counter). Screen Master 3000 Evolution (a semi-automatic laboratory analyzer) was used to measure the level of hemoglobin $(\mathrm{Hb})$ in blood.

Collection of organs for analysis. After 8 weeks of SA poisoning, the mice were sacrificed by cervical dislocation and the ventral side was opened surgically. Kidney, liver and spleen were collected using scissors and forceps. Each organ was weighed using digital balance (Precisa BJ610C) and data was recorded.

Statistical analysis. Data were statistically analyzed using Student's $t$-test with Graph Pad Prism 5.

\section{RESULTS}

Effect on hemoglobin level and neutrophils/monocytes count in mice exposed to arsenic. As an association between arsenic exposure and anemia in human has been reported earlier, ${ }^{1,15,16}$ we examined whether the normal quantity of hemoglobin in the blood of SA-exposed mice is affected or not. Compared to control, the mean concentration of hemoglobin was reduced in SAexposed mice (Figure 1). When differential count of WBC was performed, the number of lymphocytes and eosinophils were found to be unchanged between control and SA-exposed mice (data not shown). However, the neutrophil and monocyte counts were elevated and the elevation of monocytes was relatively higher (Figure 2).

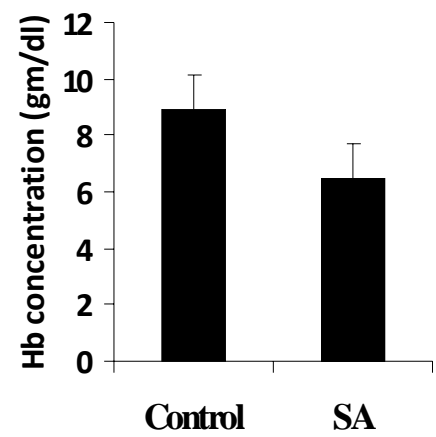

Figure 1. Reduction of hemoglobin $(\mathrm{Hb})$ level in SA-exposed mice. After collecting blood form control and SA-exposed mice for 8 weeks, Hb level was measured. Data shown as mean $\pm \mathrm{SD}$ ( $\mathrm{n}=5$ per group). ${ }^{* * *} \mathrm{p}<0.05$ control vs . As.

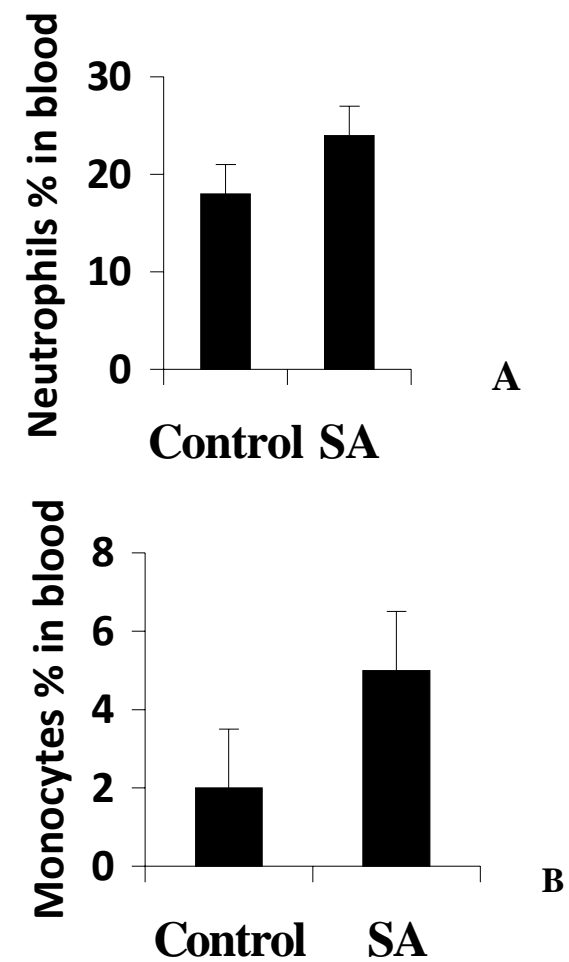

Figure 2. SA-induced elevated count of (A) neutrophils and (B) monocytes. After collecting blood form control and SAexposed mice for 8 weeks, neutrophils and monocytes count was done. Data shown as mean $\pm \mathrm{SD}$ ( $\mathrm{n}=5$ per group). $* * * \mathrm{p}<0.05$ control vs . As. 
SA induced liver and spleen enlargement. Arsenic is known to induce various diseases through affecting different internal organs. So we scarified the SA-exposed mice to see the physical change in the internal organs such as liver, spleen and kidney, if any. Interestingly, hepatomegaly and splenomegaly were evident in SA-exposed mice. The weight of liver and spleen of SA-exposed mice were found about 1.4 and 2.7 fold higher than that of control. On the other hand, average weight of kidney was decreased (1.14 fold) when compared to control (Table 1).

Table1. Effects of arsenic on the average weight of liver, spleen and kidney in mice $(n=5)$.

\begin{tabular}{lccc}
\hline \multicolumn{4}{c}{ Average weight of organ $(\mathrm{g})$} \\
\hline Organ & Control mice & SA exposed mice & Fold \\
\hline Liver & 1.39 & 1.96 & $1.4 \uparrow$ \\
Spleen & 0.099 & 0.27 & $2.7 \uparrow$ \\
Kidney & 0.32 & 0.28 & $1.14 \downarrow$ \\
\hline$\uparrow$ Increased, & $\downarrow$ Decreased. & &
\end{tabular}

\section{DISCUSISON}

Chronic arsenic exposure can lead to a range of adverse health hazards in human.,17-19 Therefore, experiments in animal model have created immense importance to find out the mechanisms of arsenic toxicity leading to development of effective remediation process. In the present study, decrease in hemoglobin level was observed in SA-exposed mice. Inorganic arsenic is reported to bind to the $\alpha$-chain of hemoglobin and thereby accumulates in the RBCs. ${ }^{20}$ Recently, we have also observed changes in RBC morphology in SA-exposed mice ${ }^{4}$ that might cause destruction of RBC leading to development of anemia. ${ }^{21}$ All these findings may support the fact of decreased hemoglobin level obtained in the present study.

Chronic arsenicosis causes severe inflammatory responses in spleen. ${ }^{22}$ In our study arsenic-induced splenomegaly was observed. The spleen enlargement might occur due to its over activity for excessive filtering or removing abnormal blood cells such as defective or dead RBC. ${ }^{22}$ In addition, enlargement of liver was found in SA-exposed mice. Prolonged drinking of arsenic-contaminated water has hepatotoxic effect. ${ }^{23-26}$ An in vitro study also showed that chronic exposure to arsenic induced malignant transformation of rodent liver cells. ${ }^{27}$ So it is possible that the liver cells in SA-exposed mice might undergo abnormal and rapid growth leading to liver enlargement. Monocytes and neutrophils counts are known to increase due to various stresses. The stress generated by the poisonous heavy metal arsenic, might cause high monocytes/neutrophils count in our study. Further investigation is needed to understand the effects of arsenic that would help to find effective ways of tratment against arsenic-mediated complications in human.

\section{ACKNOWLEDGEMENT}

This work was supported by a grant from the Ministry of Science and Information and Communication Technology of Bangladesh.

\section{REFERENCES}

1. Khan, M.M.H., Aklimunnessa, K., Ahsan, N., Kabir, M. and Mori, M. 2006. Case-control study of arsenicosis in some arsenic contaminated villages of Bangladesh. Sap. Med. J. 75, 51-61.

2. Chowdhury, U.K., Rahman, M.M., Mondal, B.K., Paul, K., Lodh, D., Biswas, B.K. 2001. Groundwater arsenic contamination and human suffering in West Bengal, India and Bangladesh. Environ. Sci. 8, 393-415.

3. Mazumder, D.N.G., Ghoshal, U.C., Saha, J., Santra, A., De, B.K., Chatterjee, A., Dutta, S., Angle, C.R. and Centeno, J.A. 1998. Randomizedplacebo-controlled trial of 2, 3dimercaptosuccinic acid in therapy of chronic arsenicosis due to drinking arsenic-contaminated subsoil water. J. Toxicol. Clin. Toxicol. 36, 683-690.

4. McKinney, J.D. 1992. Metabolism and disposition of inorganic arsenic in laboratory animals and humans. Environ. Geochem. Health. 14, 43-48.

5. Sarker, R.S.J, Ahsan, N., Hossain, K., Goush, P.K. and Akhand, A.A. 2012. Protective effects of water hyacinth (Eichornia crassipes) on sodium arsenite-mediated adverse effects in mice. Avicenna J. Med. Biotech. 4, 148-154.

6. Islam, K., Haque, A., Karim, R., Fajol, A., Hossain, E., Salam, K.A, Ali, N., Saud, Z.A., Rahman, M., Rahman, M., Karim, R., Sultana, P., Hossain, M., Akhand, A.A., Mandal, A., Miyataka, H., Himeno, S. and Hossain, K. 2011. Doseresponse relationship between arsenic exposure and the serum enzymes for liver function tests in the individuals exposed to arsenic: a cross sectional study in Bangladesh. Environ. Health. 10, 64. 
7. Benramdane, L., Accominotti, M., Fanton, L., Malicier, D., and Vallon, J.J. 1999. Arsenic speciation in human organs following fatal arsenic trioxide poisoning-a case report. Clin. Chem. 45, 301-306.

8. Kitchin, K.T. and Kirk, T. 2001. Recent advances in arsenic carcinogenesis: Modes of action, animal model sys-tems, and methylated arsenic metabolites. Toxicol. Appl. Pharmacol. 172, 249-261.

9. Rahman, A., Vahter, M., Ekström, E.C., Rahman, M., Golam Mustafa, A.H., Wahed, M.A., Yunus, M., and Persson, L.A. 2007. Association of arsenic exposure during pregnancy with fetal loss and infant death: a cohort study in Bangladesh. Am. J. Epidemiol. 165, 1389-1396.

10. Clarkson, T. W. 1991. Inorganic and organometal pesticides. In W. J. Hayes, Jr. and E. R. Laws, Jr. 43 (Eds.), Handbook of Pesticide Toxicology. Academic press, San Diego, pp. 545-552.

11. Santra, A., Maiti, A., Das, S., Lahiri, S., Charkaborty, S.K. and Mazumder, D.N.G. 2000. Hepatic damage caused by chronic arsenic toxicity in experimental animals. J Toxicol. Clin. Toxicol. 38, 395-405.

12. Akhand, A.A., Du, J., Liu, W., Hossain, K., Miyata, T., Nagase, F., Kato, M., Suzuki, H.and Nakashina, I. 2002. Redox-linked cell surface-oriented signaling for T-cell death. Antioxid Redox Signal. 4, 445-454.

13. Hossain. K., Akhand, A.A., Kato, M., Du, J., Takeda, K., Wu, J., Takeuchi, K., Liu, W., SuZuki, H. Nakashima I. 2000. Arsenite induces apoptosis of murine T lymphocytes through membrane raft-linked signaling for activation of cJun amino-terminal kinase. J. Immunol. 165, 4290-4297.

14. Hossain, K., Akhand, A.A., Kawamoto, Y., Du, J., Takeda, K., Wu, J., Yoshihara, M., Tsuboi, H., Kato, M., SuZuki, H. and Nakashima, I. 2003. Caspase activation is accelerated by the inhibition of arsenite induced, membrane raft-dependant Akt activation. Free Radic. Biol. Med. 34, 598-606.

15. Heck, J.E., Chen, Y., Grann, V.R., Slavkovich, V., Parvez. F. and Ahsan, H. 2008. Arsenic exposure and anemia in Bangladesh: a population-based study. J. Occup. Environ. Med. 50, 80-7.

16. Hopenhayn, C., Bush, H.M., Bingcang, A. and HertzPicciotto I. 2006. Association between arsenic exposure from drinking water and anemia during pregnancy. J. Occup. Environ. Med. 48, 635-43.
17. Chowdhury, U.K., Rahman, M.M., Mondal, B.K., Paul, K., Lodh, D. and Biswas, B.K., 2001. Groundwater arsenic contamination and human suffering in West Bengal, India and Bangladesh. Environ. Sci. 8, 393-415.

18. Grissom, R.E., Abernathy, C.O., Susten, A.S. and Donohue, J.M. 1999. In: Arsenic exposure and health effects. (Chapell WR, Abernathy CO, Calderon RL, Eds). Oxford: Elsevier Science Ltd. pp. 51-60.

19. Chakraborti, D., Rahman, M.M., Paul, K., Chowdhury, U.K., Sengupta, M.K., Lodh, D., 2002. Arsenic calamity in the Indian subcontinents: What lessons have been learned. Talanta. 58, 3-22.

20. Meiling, Lu., Hailin, Wang., Xing-Fang, Li., Xiufen, Lu., Cullen, W.R., Arnold, L.L., Samuel M. Cohen, and Le, X.C. 2004. Evidence of hemoglobin binding to arsenic as a basis for the accumulation of arsenic in rat blood. Chem. Res. Toxicol. 17, 1733-1742.

21. Blair, P.C., Thompson, M.B., Bechtold, M., Wilson, R.E., Moorman, M.P., and Fowler, B.A. 1990. Evidence for oxidative damage to red blood cells in mice induced by arsine gas. Toxicology. 63, 25-34.

22. Sakurai, T., Kaise, T. and Matsubara, C. 1998. Inorganic and methylated arsenic compounds induce cell death in murine macrophages via different mechanisms. Chem. Res. Toxicol. 11, 273-283.

23. Chiu, H.F., Ho, S.C., Wang, L.Y., Wu, T.N. and Yang, C.Y. 2004. Does arsenic exposure increase the risk for liver cancer. J. Toxicol. Environ. Health. 67, 1491-1500.

24. Centeno, J.A., Mullick, F.G., Martinez, L., Page, N.P., Gibb, H., Longfellow, D., and Thompson, C. 2002. Pathology related to chronic arsenic exposure. Environ. Health Perspect. 110, 883-886.

25. Morales, K.H., Ryan, L., Kuo, T.L., Wu, M.M. and Chen, C.J., 2000. Risk of internal cancers from arsenic in drinking water. Environ. Health Perspect. 108, 655-661.

26. Mazumder, D.N. 2005. Effect of chronic intake of arseniccontaminated water on liver. Toxicol. Appl. Pharmacol. 206, 169-175.

27. Zhao, C.Q., Young, M.R., Diwan, B.A., Coogan, T.P. and Waalkes, M.P. 1997. Association of arsenic-induced malignant transformation with DNA hypomethylation and aberrant gene expression. Proc. Natl. Acad. Sci. 94, 1090710912. 